\title{
Elisabetta Vinci
}

\section{Empathy in Modern Drama: Bertolt Brecht's Threepenny Opera}

\section{Introduction}

Writing about theatre and neuroscience is not easy because humanities and science follow different paths and use opposite methods. Moreover, a widespread scepticism permeated both scientists and artists as far as an interdisciplinary analysis of theatre is concerned. Recently, the ancient dichotomy between arts and sciences, specifically neurosciences and cognitive sciences, has been overcome thanks to open-minded scholars who struggled to give a different perspective on both disciplines and showed on the one hand how cognitive sciences can be useful to better understand the creative process and the perception of arts; on the other hand, how arts can be important for scientists to shed light on some of the most complex brain processes. The interdisciplinary approach to the study of art can reveal new scenarios, especially with regard to the relationship between artists and audience. The discovery of mirror neurons by the team of the University of Parma, composed of Giacomo Rizzolatti, Vittorio Gallese, Luciano Fadiga, and Leonardo Fogassi, provoked a revolution in the scientific field, providing new instruments to investigate the biological response to work of arts, because mirror neurons give a biological explanation to empathy. As a consequence, in recent years, arts, in particular performing arts, have been investigated, with very interesting results, starting from a neuroaesthetic and cognitive perspective.

On the heels of these studies, this paper aims to examine the mechanisms of empathy in the epic theatre theorized by Bertolt Brecht with particular attention to the Threepenny Opera. The choice of this topic derives from the different conception of the German author regarding empathy, that is the pivotal element of performing arts, while, according to Brecht, it was instead to be rejected. According to his theory, spectators must critically reflect on the drama and not be emotionally involved in it. On the contrary, the premiere of the Threepenny Opera conquered the appreciation of the audience, despite Brecht's intentions. What I propose is an analysis of the features of the Brechtian drama, in comparison to 
the results of experiments carried out by neurobiologists about the perception of art, in particular, empathy. The analysis allows us to clarify the reasons of the great success of the show in contrast to Brecht's assumptions and that empathy, whose mechanism can be scientifically demonstrated, is the basis of any theatrical form.

\section{Empathy, Mirror Neurons and Theatre}

The concept of empathy has been investigated in various disciplines, such as psychology, philosophy, medicine, and aesthetics. Vischer (1873) used the term Einfühlung - translated with empathy - in the field of aesthetic philosophy to refer to the physical reactions produced by the observation of paintings. Lipps (1903) employed it in the field of psychology to describe the deep participation in the experience of another being. In this case, the distance between two subjects is cancelled and a single self is created: the empathic subject is not an "I but a we" (Fogliani, 2003, p. 65). In a nutshell, empathy is the medium to comprehend other people's emotions and actions and to identify with what we define as "other". It is an instrument to overcome the boundaries of the personal experience and open the self to the world. For this reason, empathy is a key concept not only in social sciences and anthropology but also in the field of arts, since it is the basis of the relationship between artworks' production and reception.

In recent years, neurobiological studies started to concentrate on the cerebral mechanisms of aesthetic appreciation, to understand how human body responds to external stimuli concerning artistic works (Maffei \& Fiorentini, 1995; Zeki, 1999). The importance of such studies lies in the assumption regarding the relationship between feelings and emotion arising from the observation of artworks and bodily response, because it shows how brain is closely linked to body. Basis of this idea is the discovery of mirror neurons, occurred in Parma in the 1990s thanks to the team led by Prof. Giacomo Rizzolatti. This peculiar kind of cells activates not only when people act directly but also when they observe an action performed by someone else (Iacoboni, 2008). Furthermore, they activate also at the sight of objects than can be grasped (Iacoboni, 2008, p. 20). The existence of these types of cells contradicts the thesis that action and perception are separated and allow to assume that it is possible to recognize other people's actions and, as a consequence, to understand the specific purposes associated with the action. In short, mirror neurons allow us to comprehend other people's intentions. This is possible because when "we look at someone performing an action, beside the activation of various visual areas, there is a concurrent activation of the motor circuits that are recruited when we ourselves perform that action" (Gallese, 2003, p. 174). Embodiment, indeed, implies the involvement of body in the comprehension of both actions performed by others and emotions. The neurophysiologist Gallese $(2001,2003,2007,2008)$ used the expression "embodied simulation" to define 
this bodily imitation of the observed action. Even if we do not move, our motor system reacts as if we were performing the action we observe. The neuroscientist Damasio (2000) talked about an "as if loop" to indicate the internal simulation of bodily changes created in the somatic sensory maps without a real bodily modification. So, as Gallese (2003) highlighted, empathy involves the sharing of different states, such as motor actions, body schema and emotions; for this reason, he introduced the concept of "shared manifold of intersubjectivity" (Gallese, 2001, 2003) that can be applied to all different levels. Thanks to the shared manifold, we are able to empathize with other people and "intersubjective communication, social imitation and ascription of intentionality become possible" (Gallese, 2003, p. 177). For this reason, it can be affirmed that mirror neurons and the resulting embodied simulation are the biological (and neurobiological) bases of empathy; they are the foundation of intersubjectivity and allow us to recognize other people similar to us, so that when we are in front of "another self" and we can penetrate its internal world, establish a relationship with it and share its bodily and emotional states. Embodied simulation is indeed closely linked to the mere observation of other people's expressions, since when we look at them "feedback from the motor system triggers a cascade of neural activations in other brain regions involved in the emotional experience, eliciting the correspondent experience in the perceiver" (Gallese \& Caruana, 2016, p. 397). Proving that human brain is made to simulate, mirror and understand others, neuroscientific studies make empathy an essential element for sociability, because "it is the necessary condition to shift from narcissism and subjectivity to reciprocity" (Fogliani, 2003, p. 65). If simulation and mirror neural mechanisms are peculiar of men, it can be stated that intersubjectivity is ontologically the basis of human condition and it is closely linked to intercorporeality as it will be explained later. Studying empathy mechanisms means to study the mechanisms of intersubjectivity and understand the process of identification with other people. In this sense, the difference between empathy and sympathy must be clarified (see Wispé, 1986). While sympathy implies feeling compassion towards other people, empathy only indicates the human inclination to understand actions and emotions experienced by others, "sharing something of the other's feelings without necessarily feeling affection, positive regard or the desire to help" (Chismar, 1988, p. 258).

Of course, these studies in the field of empathy have implications in the artistic and, more specifically, theatrical field, because, as anticipated, empathy is at the basis of the relationship between artworks and spectators, drama and audience. Nevertheless, it is interesting to investigate, from a neurobiological perspective, what happens to the audience during a theatrical play, and which mechanisms make immedesimation possible. This aspect will be investigated in the next paragraph, dedicated to the analysis of empathy in the Threepenny Opera by Bertolt 
Brecht, to understand if the Brechtian theory concerning alienation is possible or not, in light of recent neuroscientific discoveries and studies.

In particular, it is very important to analyze empathy in relation to drama because theatre is par excellence the art that simulates life and it is based on the connection between what happens on the stage and the reaction of the audience, in short, on the relation between actors and spectators, since the creation of an empathic relationship and the emotional participation of the audience are necessary conditions for the success of the performance.

\section{The Brechtian Revolution}

In the 1930s, Bertolt Brecht theorized a new vision of theatre, which aimed to revolutionize the effects of the performance on the audience. In his essay collections, Brecht On Theatre (Brecht, 1964), the author deeply explains his idea of drama and wonders if theatre is still able to communicate the complexity of contemporary world. According to Brecht, modern theatre is mostly "culinary" (Brecht, 1964), because it provokes entertainment and body relief, as food does. This kind of theatre exploits empathy and emotions to involve the audience but it actually has no effect on people's critical ability, while, in Brecht's opinion, audience must not feel: it has to learn, reflect and think. Brecht wanted to destroy culinary theatre and establish a kind of theatre defined by himself as antiAristotelian, alienating and epic. It is anti-Aristotelian, namely Copernican, because it is neither geocentric nor anthropocentric; in fact, it does not place the character as the focus of the action and it does not aim at empathy and catharsis, but stages the relationships among characters, because human existence is conceived as a result of social relations. It must also be alienating, so that spectators look with detachment at the representation, being able to criticize the work. Finally, his theatre is epic because it aims to produce knowledge through the critical narration of facts and, as a result, to provoke a sociopolitical transformation of reality. In the transition from the dramatic to the epic form of theatre, various changes occur in the fundamental elements of the theatrical conception, as explained by Brecht in the work The Modern Theatre is the Epic Theatre (Brecht, 1964, pp. 33-42) composed as a set of notes to the play Rise and Fall of the City of Mahagonny. The most important changes concern the position and the attitude of spectators in front of the stage action. In the dramatic form, audience is supposed to be part of the action, and it must be attracted by the scene, that has the aim of provoking strong feelings and emotions. Human beings are considered as fixed and immutable; feelings and sensations are at the core of the performing strategies. In the epic theatre, on the contrary, audience must develop a critical point of view about the action. Instead of being involved in the action, spectators must be placed in front of something, in an external position, so that they have 
the possibility of thinking, analyzing the situation and being able to make autonomous decisions without being influenced by emotions. Brecht (1964, p. 66) wrote: "modern spectators, it was assumed, do not want to meekly succumb to a kind of hypnotic suggestion or to forfeit their reason by getting sucked into all sorts of emotional states". Epic theatre emphasizes rationality instead of feelings, thus proposing a fight against empathy. The elimination of empathy does not imply apathy, but rather a detached and critical gaze and stimulates commitment and will to change reality, a view attributable to the Marxist Weltanschauung. In addition, recitation techniques need to be changed, so as to obtain an alienating effect. Alienation (Verfremdung) - in opposition to empathy - permits the accomplishment of the principal aim of Brechtian theatre: prevent the audience to be emotionally involved and indulge in uncontrolled feelings (Brecht, 1964, p. 63).

\section{The Threepenny Opera}

The Threepenny Opera can be considered the maximum example of epic theatre. It was staged by Bertolt Brecht in 1928 at the Theater am Schiffbauerdamm in Berlin with music by Kurt Weill and set design by Caspar Neher. The text was a reinterpretation of the play by John Gay The Beggar's Opera composed in 1728, intended to be a satire of the English society. Main character of the Brechtian drama is Jonathan Peachum, who represents the dependence of men by basic needs. He would like to be a good man but social conditions do not allow him to be so. Macheath, known as Mack the Knife, has the appearance of a bourgeois gentleman but is actually an unscrupulous murder and criminal; Brown is the Commissioner of police of London but he is corrupt and a friend to Mack. Main female characters are Polly, Peachum's daughter and future wife of Macheath, and Jenny, Mack's favourite prostitute who will betray him. This drama is a denunciation of the bourgeois society and shows, in a Marxist perspective, how human beings are conditioned by circumstances and how evanescent is the dividing line between honest and corrupt people, because morals are subject to basic needs, as Macheath in act II, scene III sings: "Food is the first thing, moral follows on" (Erst kommt das Fressen, dann kommt die Moral, Brecht, 1928/2002, p. 144). But more relevant here is the audience reaction to the representation in contrast to Brecht's idea about it. In this drama, the German author used the "alienation effects", called A-effects (Verfremdungseffekte) to achieve his main purpose: stimulate the critical judgment of the audience. Brecht indeed aimed to replace catharsis and empathy with "alienation", that is to transform the obvious and evident elements of characters and events to originate curiosity or surprise about them (see Ewen, 1970, p. 187), in short "alienating the familiar" (Brecht, 1948, p. 9). Alienation effects involved all elements of the theatrical ensemble: actors, music, chorus, stage design, and lighting. For example, since darkness in the 
parterre and half-light on stage contribute to the immersion of spectators, they should be avoided: the scene must be well illuminated and every character on stage must be illuminated with the same light intensity. Moreover, illumination devices do not have to be hidden but visible to make the theatrical illusion clear. Epic theatre with its alienation effects was the possible solution offered by Brecht to adequate theatre to reality and allowed audience to develop a critical thought on the world.

This paper aims to show that the A-effects actually are not so effective, because, as recent discoveries demonstrate, empathy, emotional and physical involvement cannot be avoided, since they are closely linked to human biological and neurological system and activated by any kind of art experience.

Indeed, the Threepenny Opera did not achieve the result Brecht worked for. After the premiere in Berlin in 1928, the audience was enthusiastic about the show, in particular about music and songs. Brecht did not imagine to receive such appreciation by bourgeois audience, because it was the kind of people he attacked and wanted to upset, yet the same problem occurred some years before with Drums in the night. In the preface to this play, he expressed his disappointment: he felt like someone who after shooting with a cannon towards a group of people he disliked, saw them running shouting cheers to his address because he had accidentally fired a lot of loaves on them (Brecht, 1923/2010). He was conscious that something went wrong with regard to his idea concerning epic theatre. To explain how this was possible, the A-effects related to the different elements of theatre will be compared to neurobiological studies and experiments.

\subsection{Music}

In the epic theatre, music must not be melt in the show but it must act as a comment about the play and be independent from it, namely the orchestra must be placed on stage and illuminated during musical executions, in order to be clearly seen by the audience, avoiding the melting of action and music and rejecting the full immersion of spectators. Furthermore, the song titles appeared on a screen placed on the backdrop and actors often addressed the audience to inform it of the song they were going to sing, to break the rhythm. Thanks to the collaboration of Kurt Weill, music was used in a "modern perspective" (Vigliero, 2002, p. XX). Weill decided to use different musical genres for the Threepenny Opera, from the Moritat of folk tradition, to cabaretistic, operatic and jazz music very popular in the 20s. The aim was that of alienating the audience and unmasking bourgeois identity, instead songs from the Threepenny Opera became immediately familiar to spectators, thus contributing to the success of the drama, to the point that everybody sang Mack the Knife's ballad in the street of the city after the premiere (Ewen, 1970, p. 142). Moreover, spectators have completely been captured 
during the Cannon song (act II, scene I) sung by Macheath and Brown, and Lotte Lenya (the actress performing Jenny) told at that point of the show there was an incredible clamour and the audience was in turmoil, so she understood that nothing could go wrong because spectators were on their side (Ewen, 1970, p. 142).

Scientific experiments in the field of neurophysiology show that music evokes similar affective sensory-motor resonances in both the player and the listener. The theories of Gallese and Freedberg (Freedberg \& Gallese, 2008) regarding the observation of works of art state that the crucial element in aesthetic appreciation consists in the activation of universal embodied mechanisms capable of simulating actions, emotions and sensations. The idea underlying the theory is that there is an identification of the observer with the artist, then a physical imitation of gestures and inner emotions. Such identification occurs also when we listen to live music; indeed, in this case, the embodied simulation is increased by the direct view of the musicians' gesture. Since the orchestra is placed on stage, it is visible from the audience, thus causing the activation of mirror mechanisms as if spectators took part in the performance. Experiments carried out by Chen, Penhune, and Zatorre (2008) through functional magnetic resonance imaging (fMRI) demonstrate that the mere listening of music and sounds provokes the activation of the motor system. What is more relevant is that this happens not only when we listen carefully to well-known passages but also in the case of a passive listening. This is the reason why we spontaneously move when we listen to sounds and music. There are also more recent studies proving that motor system plays a central role in the perception of both music and rhythm (Gordon, Cobb, \& Balasubramaniam, 2018). Furthermore, Salimpoor, Benovoy, Longo, Cooperstock, and Zatorre (2009) showed that the sensation of pleasure caused by the music has implications in heartbeat, breathing, body temperature and blood pulsations too. It is therefore clear that the conscious pleasure in listening to music produces unconscious physiological changes. As far as the epic performance is concerned, in light of these data, I think that the involvement of spectators during the musical tracks is inevitable, despite the measures adopted by Brecht to use music in a new and alienating way and despite the singing of the actors that in a certain sense "goes against the music" instead of following the melody. Taken into account that Weill also uses popular music or songs well known to the audience, such as the tango in the Pimp's Ballad, it is easier to understand the enthusiasm of the audience in hearing familiar sounds.

\subsection{Acting}

Performing arts, unlike other art forms, has a peculiar feature: the coincidence of the creating subject with the created object; in short, artist and artwork correspond (see Falletti, 2004). The body of the actor is the artistic object of the 
theatre, transforming the single spectator in a member of a unitary group, the audience. According to Gallese (2010), this strong interpersonal relationship displays mimetic mechanisms based on the embodied simulation. In this regard, neurosciences provide sufficient evidence to affirm that in the relationships based on intersubjectivity, the individual can have direct access to the world of other subjects thanks to shared nervous mechanisms, such as mirror neurons. Gallese speaks precisely of intercorporeality, because such mechanisms establish a form of identification with other people, allowing, in any case, to preserve the otherness of each one. Mirror neurons and in particular embodied simulation are fundamental for the comprehension of empathy and can give us important information about the relationship among actors/audiences also with regard to the epic theatre. Brecht insisted so much, both in the Short Organum for the theatre and in the notes to the Threepenny Opera, on acting technique, underlining that actors must remain distant from the characters, so that spectators should not be initiated on the path of identification. "In order to produce A-effects the actor has to discard whatever means he has learnt of getting the audience to identify itself with the characters which he plays. Aiming not to put his audience into a trance, he must not go into a trance himself" (Brecht, 1948, p. 9), so his feelings must not coincide with character's feelings. Empathy must be avoided by both actors and audience. Analyzing neuroscientific discoveries, it can be stated that the absence of empathy in the theatre is nearly impossible because electromyographic reactions in the facial muscles of the observers correspond to those involved in the facial expressions of the observed person, so the observer can reconstruct a certain emotion through the simulation of its body state (Freedberg \& Gallese, 2008, p. 57). A big step has been carried out by Antonio Damasio and his collaborators (Damasio, 2000; Kawasaki et al., 2001), who demonstrated that feelings are associated with the neuronal maps of the corresponding physical state, which means that some areas of the brain of the observer react as if they were directly engaged in the same actions or were subject to the same conditions as the person observed. Implications of these results in empathy are obvious and applicable to the theatrical context, because it must be highlighted that human mirror neurons activate also when observing the mimed actions. Spectators in the parterre are inevitably subject to the simulation mechanisms while not being aware of it. In the end, Brecht's recommendations and instruction for actors are not effective, because, even if unconsciously, they are the starting points of the empathic relationship.

\subsection{Gesture}

Gesture is the expressive peculiarity of the human body and, consequently of the actor: it can be performed with hands, head or with the whole body; it is 
the bridge between the action and the brain, the vehicle through which mood, emotions, feelings, and thoughts are represented. As demonstrated by cognitive neurosciences, mind and body, thought and gesture, cannot be separated; for this reason, it can be argued that it is impossible to put into practice what Brecht aimed to, that is that the audience would laugh at the crying actor and cry at the laughing actor. According to the playwright, crying can arouse laugh and vice versa, because in the epic theatre what happens on stage is surprising, nothing is obvious, so, unlike in dramatic theatre, spectators are not in the condition to say "I've felt that way too", instead they would say "I hadn't thought of that" (see Brecht, 1964). Several experiments show that spectators' reactions correspond to actors' expressions, for example, Warren et al. (2006) demonstrate that the mere listening to sounds ascribable to amusement and exultation activates the same motor areas required for the smile. Moreover, results of similar experiments, conducted to investigate the expression of disgust, show that the same restricted brain region is activated both during the first person experience and during the observation of facial expressions of disgust in other individuals (Wicker et al., 2003). Through gesture, therefore, we are able to experience what others feel and to respond empathically to their emotional states. These results can be applied to some scenes of the Threepenny Opera, such as the third scene of the third act in which Macheath, betrayed, is destined to go to the gallows. The audience will be moved to pity because of Macheath's fear of dying expressed by the character. On the contrary, during the Cannon Song, the audience was transported by the complicity and the movement of Mackie and Brown. And again, while Jenny sings her song, her resentment and desire for revenge penetrate the heart of spectators, thanks to the combined action of music, words and gesture. It is necessary to underline that there are two kinds of gesture: iconic or pulsation indicators. The first ones reflect the content of the speech they accompany, and the second ones are rhythmic movements that mark the time of speech. It has been ascertained, through a neuroimaging experiment, that mirror neurons activate with greater intensity during the observation of iconic gestures, because they simplify the understanding of the speech, so the gestures made by the actors do nothing but facilitate empathy (Iacoboni, 2008, p. 76).

\subsection{Words and Sounds}

Another fundamental tool of acting is the speech. A form of mirroring also exists in the field of verbal communication: as verified (Iacoboni, 2008a; Wilson, Saygin, Sereno, \& Iacoboni, 2004) our brain perceives the words of other people through a simulation, as if we were directly speaking, since the sounds produced by language are understood as articulatory gestures, i.e. intentional motor projects 
necessary to speak. Blind people, in fact, have much more difficulties and are slower in the perception of speech. In Italy, Luciano Fadiga and his team (2002) carried out this kind of experiments, finding that if a subject listens to phonemes that require strong movements of the tongue (for example the double $r$ of the Italian "terra") the tongue contracts as if it should produce those sounds. If someone listens to phonemes that require reduced movements (such as the double f of the Italian "baffo"), the tongue is only marginally active. So, listeners internally simulate other people speaking with the reaction of their tongues, understanding more easily what is being said and, shifted to theatre, this undoubtedly favours the identification of spectators with talking actors. Moreover, mirror neurons encode the actions performed by other people in a complex way, activating even with the sole sound that comes from the actions performed: if we hear the noise of ripped paper, we unconsciously simulate the action of tearing up a piece of paper, thus confirming the strong link between perception and body simulation. In the case of the epic theatre, the pronunciation of sentences that are familiar to the audience, such as the biblical or literary quotations of the Threepenny Opera, facilitates the mechanism of identification, given that brain response is more intense in case of familiar stimuli (Pereira et al., 2011).

\subsection{Dance}

Dance is an important element in theatre, even more in case of a ballad opera like the Threepenny Opera in which dialogues are accompanied by musical pieces and songs. In Brecht's play, there are some scenes in which characters dance, for example during the Cannon Song sung by Macheath and Brown. They hit with their feet to the rhythm of music improvising a kind of march and, in the 1972 version staged and directed by Giorgio Strehler in Milan, other men join the dance. In the second scene of the second act, Mack the Knife and Jenny sing the Pimp's Ballad while they tell their story; the music is that of a very popular tango and the two characters hint at a tango dance. So, it is important to understand how human brain reacts to the sight of dancing bodies. Beatriz Calvo-Merino deepened this aspect and studied the cerebral reactions of people observing dancers. Thanks to fMRI, she and her team examined the reaction of the mirror system in front of videos of different choreographies. Subjects involved in the experiment were professional classical dancers, capoeira dancers and inexperienced people. The results showed that the activation of mirror neurons is greater when observing movements that are known to us and we have learned to perform; so, classic dancers have shown a stronger reaction in front of movements typical of a classic ballet and weaker reaction when looking at the capoeira. The inexperienced, on the other hand, reacted much less to visual stimuli, but however the activation of the mirror system associated with the execution of the observed movements was 
verified in their brain (Calvo-Merino, Glaser, Grezes, Passingham, \& Haggard, 2005). The experiment suggests that our brain associates, through mirror neurons, the actions it sees with those of the known motor repertoire, performing an internal - or better embodied - simulation, recording a stronger activity of the mirror system if a movement is already known and less if it is not. When spectators look at a dance performed on stage, their reaction will be different depending on their greater or lesser experience of that type of movement; in any case, their mirror system will activate.

\section{Conclusions}

The neural study of intersubjectivity and of the fundamental role played by embodied simulation allows to understand the active role of the audience in the theatre and to look at performing arts from a different perspective. As far as my study is concerned, starting from the neuroscientific discoveries regarding empathy, it is possible to hypothesize which cerebral mechanisms activate in the audience and which kind of reaction occurs when attending a theatrical pièce, like the Threepenny Opera, that should contrast empathy. The results have provided sufficient data to state that the assumptions of the epic theatre, as elaborated in the Threepenny Opera, have the opposite effect of the desired one and to hypothesize the scientific reason for its enormous "empathic" success despite the epic structure.

In conclusion, through the analysis and the study of neuroscientific experiments conducted on human beings, it is possible to argue that the absence of empathy and identification theorized by Brecht is impossible to be achieved on stage, because they are based on biological sharing mechanisms. Furthermore, the harmony of dance, music and gesture favours identification and emotive involvement. These results may explain the partial failure of this idea of theatre which, after Brecht, has been pursued by other playwrights. My research is just a very small example of how the dialogue between theatre and neuroscience, or more generally between art and science, may allow us to understand some phenomena that in both areas are still lacking in a satisfactory explanation.

\section{Summary}

The aim of this paper is to compare Brechtian theory concerning empathy in theatre and recent studies showing the biological basis of empathy. First of all, a brief summary about the concept of empathy is provided, with particular attention to empathy in Brechtian theatre. Then, a paragraph is dedicated to explain how empathy and emotional involvement are linked to neurobiological mechanisms and body state. In the end, an analysis of the Verfremdungseffekte in the Threepenny Opera is traced to understand how recent studies contradict Brechtian theory as far as empathy is concerned.

Keywords: Empathy, theatre, Brecht, mirror neurons. 


\section{Empathie im Modernen Drama: Brechts' Dreigroschenoper}

\section{Zusammenfassung}

In diesem Beitrag soll Brechts Theorie zur Einfühlung am Theater mit jüngsten Studien zu den biologischen Grundlagen von Empathie verglichen werden. Zunächst wird eine kurze Zusammenfassung des Konzepts der Empathie vorgestellt, mit besonderer Beachtung der Einfühlung im Brecht'schen Theater. Im weiteren wird dargelegt, wie Empathie und emotionale Beteiligung mit neurobiologischen Mechanismen und körperlichen Zuständen verbunden sind. Schließlich wird eine Analyse der Verfremdungseffekte in der Dreigroschenoper nachgezeichnet, um verständlich zu machen, wie jüngste Studien der Theorie von Brecht in Bezug auf Empathie widersprechen.

Schlüsselwörter: Einfühlung, Theater, Brecht, Spiegelneuronen.

\section{References}

Brecht, B. (2010). Trommeln in der Nacht. Komödie. 19. Auflage. Frankfurt am Main: Suhrkamp (Original work published 1923).

Brecht, B. (2002). Die Dreigroschen Oper (L'opera da tre soldi, E. Castellani Trans.). Torino: Einaudi. (Original work published 1928).

Brecht, B. (1948). A short Organum for the theatre. Retrieved from tenstakonsthall.se/uploads/139-Brecht_A_ Short_Organum_for_the_Theatre.pdf [16.01.2019].

Brecht, B. (1964). Brecht on theatre. The development of an aesthetic. New York, NY: Farrar, Straus and Giroux.

Calvo-Merino, B., Glaser, D. E., Grezes, J., Passingham, R. E., \& Haggard, P. (2005). Action observation and acquired motor skills: an fMRI study with expert dancers. Cerebral Cortex, 15, 1243-1249.

Chen, J. L., Penhune, V. B., \& Zatorre, R. J. (2008). Listening to musical rhythms recruits motor regions of the brain. Cerebral Cortex, 18, 2844-2854.

Chismar, D. (1988). Empathy and sympathy. The important difference. The Journal of Value Inquiry, 22, $257-266$.

Damasio, A. (2000). The feeling of what happens. Body and emotion in the making of consciousness. Wilmington, DE: Mariner Books.

Ewen, F. (1970). Bertolt Brecht. La vita, l'opera, i tempi. (A. D’Anna Trans.). Milano: Feltrinelli.

Fadiga, L., Craighero, L., Buccino, G., \& Rizzolatti, G. (2002). Speech listening specifically modulates the excitability of tongue muscles: a TMS study. European Journal of Neuroscience, 15, 399-402.

Falletti, C. (2004). Neuroscienze cognitive e teatro, Un master europeo di studi sull'attore. Biblioteca teatrale, $71-72,1-5$.

Freedberg, D., \& Gallese, V. (2008). Movimento, emozione, empatia. I fenomeni che si producono a livello corporeo osservando le opere d'arte. Prometeo, 103, 52-59.

Fogliani, T. M. (2003). Empatia ed emozioni. Catania, Italy: C.U.E.C.M.

Gallese, V. (2001). The 'shared manifold' hypothesis: From mirror neurons to empathy. Journal of Consciousness Studies, 8, 33-50.

Gallese, V. (2003). The roots of empathy: The shared manifold hypothesis and the neural basis of intersubjectivity. Psychopathology, 36, 171-180.

Gallese, V. (2007). Dai neuroni specchio alla consonanza intenzionale. Meccanismi neurofisiologici dell'intersoggettività. Rivista di Psicoanalisi, LIII, 197-208.

Gallese, V. (2008). Il corpo teatrale: mimetismo, neuroni specchio, simulazione incarnata. Culture Teatrali, 16, 13-38.

Gallese, V. (2010). Corpo e azione nell'esperienza estetica. Una prospettiva neuroscientifica. In U. Morelli (Ed.), Mente e Bellezza. Arte creatività e innovazione (pp. 245-262). Torino, Italy: Allemandi.

Gallese, V., \& Caruana, F. (2016). Embodied simulation: Beyond the expression/experience dualism of emotions. Trends in Cognitive Sciences, 20(6), 397-398. doi:10.1016/j.tics.2016.03.010

Gordon, C. L., Cobb, P. R., \& Balasubramaniam, R. (2018). Recruitment of the motor system during music listening: An ALE meta-analysis of fMRI data. Plos One, 13(11), doi:10.1371/journal.pone.0207213.

Iacoboni, M. (2008). I neuroni specchio. Come capiamo ciò che fanno gli altri. Torino, Italy: Bollati Boringhieri. 
Iacoboni, M. (2008a). The role of premotor cortex in speech perception: Evidence from fMRI and rTMS. Journal of Physiology-Paris, 102(1-3), 31-34.

Kawasaki, H., Kaufman, O., Damasio, H., Damasio, A. R., Granner, M., Bakken, H., ... Adolphs, R. (2001). Single-neuron responses to emotional visual stimuli recorded in human ventral prefrontal cortex. Nature Neuroscience, 4, 5-16.

Lipps, T. (1903). Ästhetik. Psychologie des Schönen und der Kunst. Hamburg/Leipzig, Germany: Voss.

Maffei, L., \& Fiorentini, A. (1995). Arte e cervello. Bologna, Italy: Zanichelli.

Pereira, C. L., Texteira, J., Figurerido, P., Xavier, G., Castro, S. L., \& Brattico, E. (2011). Music and emotion in the brain: familiarity matters. Plos One, 6(11), doi:10.1371/journal.pone.0027241.

Salimpoor, V. N., Benovoy, M., Longo, G., Cooperstock, J. R., \& Zatorre, R. J. (2009). The rewarding aspects of music listening are related to degree of emotional arousal. Plos One, 4, 1-14.

Vigliero, C. (2002). Introduzione a L'Opera da tre soldi, in B. Brecht, Die Dreigroschen Oper (L'opera da tre soldi, E. Castellani Trans.). Torino: Einaudi. (Original work published 1928), V-XXII.

Vischer, R. (1873). Über das optische Formgefühl-ein Beitrag zur Ästhetik. Leipzig, Italy: Hermann Credner.

Warren, J. E., Sauter, D. A., Eisner, F., Wiland, J., Dresner, M. A., Wise, R. J. S., ... Scott, S. K. (2006). Positive emotions preferentially engage an auditory-motor "mirror" system. Journal of Neuroscience, 26(50), 13067-13075. doi:10.1523/JNEUROSCI.3907-06.2006.

Wicker, C., Keysers, C., Plailly, J., Royet, J. P., Gallese, V., \& Rizzolatti, G. (2003). Both of us disgusted in insula: The common neural basis of seeing and feeling disgust. Neuron, 40, 655-664.

Wilson, S. M., Saygin, A. P., Sereno, M. I., \& Iacoboni, M. (2004). Listening to speech activates motor areas involved in speech production. Nature Neuroscience, 7, 701-702.

Wispé, L. (1986). The distinction between sympathy and empathy: To call forth a concept, a word is needed. Journal of Personality and Social Psychology, 50(2), 314-321. doi:10.1037/0022-3514.50.2.314

Zeki, S. (1999). The inner vision. Oxford, England: Oxford University Press.

Elisabetta Vinci, born in 1989, studied foreign language and literature at the University of Catania (Italy), where she obtained her $\mathrm{PhD}$ in Cultural Heritage. Her dissertation focuses on comparison between central European and Sicilian puppetry, to show the common roots of this heritage. Her research interests and publications concern German literature and culture, theatre and cognitive narratology.

Address: Università degli Studi di Catania, Dipartimento di Scienze Umanistiche, Piazza Dante 32, 95124 Catania, Italy.

Email: elisabetta.vin@gmail.com 